\title{
Confucian Tradition and the Challenges of Trust and Accountability.
}

\author{
JONGRYN MO \\ Graduate Schm: of Intemiztional Studies, Yonsei inswersits
}

This patate extiones the relerance of sulture for undersanding the quality of gotsmunce in contentporary Korta. Beginning with defrnitisn and

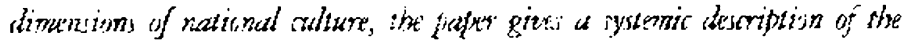

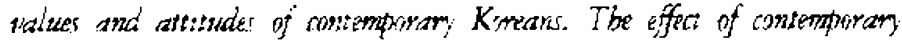

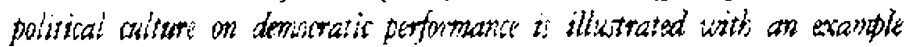

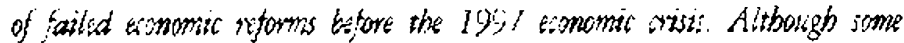

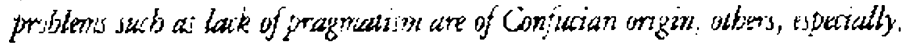

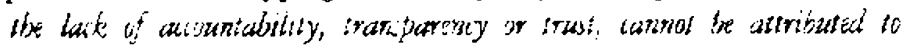

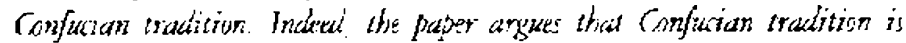

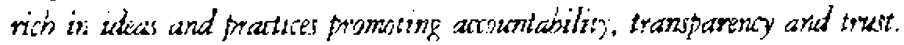
Witbout fuily understanding Confucian itaktion mam scholars tane been

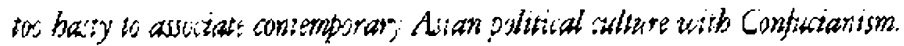

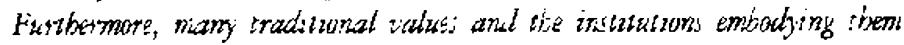

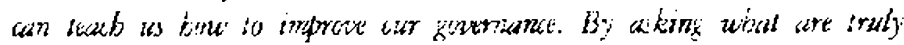

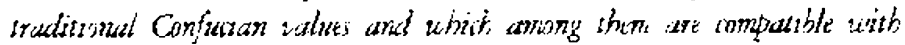

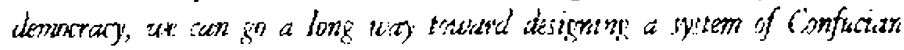
scremance.

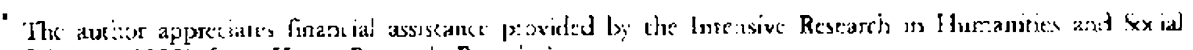
Sciences (19\%3) from Kore: Researth Founcitior.

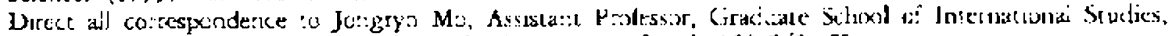

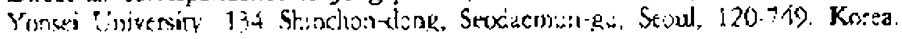




\section{INTRODLCTION}

Covernance is curren:y a fashionable :opic. Not only does the political esta-

J blishment debate the issise, unlikely participartss such as corponate toards (a la corporate governance) and development banks (e.g., the World Banks New Development Paradigm have aso jeen drawr. inio the debate. What, however, is the mear.ng of jovurnance anci how co rie attain it: Good governance car. be measured by the ability of a poltici system. to produce good poicies. Guxi pclicies, in thim, ars those tha: (I) are generally oulentuci toward desrable social goals (such as exononic gasth), (2) are corsistent and coterest and (3) reflect boad mational interests rather

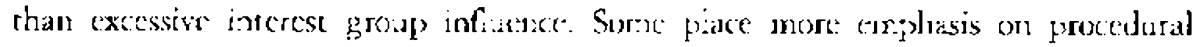
conditions than on stbxtantive aspers of poicies, namely, sarsjarent poixyraking p-ocess, arcointability ct government offic:als anc broad participaticr by stakeholders. Defiring what constirutes good goverrance appeas straight:orward, but is reality, it is difficult to form a consensus on priorities. How to actually reeasure the quality of governance is also ccntroversial anc recinical, as snown by recent artempes to measure the production of laws by difterent legislatures (Maybew loy)!

Conseguenty, there is no consensus on hww so at:ain good governance, whet is surprising, since the u'timate goa' of poibical science ss to identify necessary and

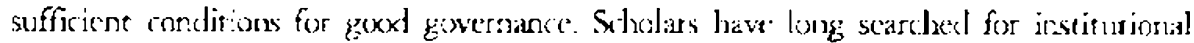
atranj̧ements condicive to good policy chnices. Yer, although at the system lovel democrary supposedly produces berter governance than authoriariazisn, instiruricnal arrangements a'so vary wide'y across courrries with the same regime, whether democra:ic or authcritariar. A demoxratic government can, for example, choose either a presidential or pasjamentary system, and this choice is an important vatiable artecting its pe:tornarices.

Furhetrore, it would be a rastake to foces only on instituticns without examining th:e bacacer sexial environments in which :hey are emledded. Broad sexial corditions are important berause they affect the duoce of instirt.tions as well as thej subsequent effextiveness. For example, in orck: for demorary to work smoorhly, the existence of certain values and attitudiss: such as trust, rolemance and accommodation, is necessary.

In this paper, I expore the reievance of culture for understanding rine cuaity of gevernance in contemporary Korea. Begirning with definirions and dimensions of na:ional culni:e, I atrempt to give a systerric cescription ot the vaiues and attinujes of contemporary korears. How cortemporary posticá culture affects demoratic per-

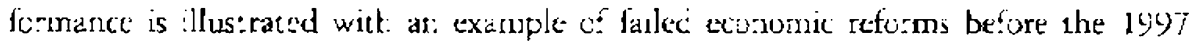

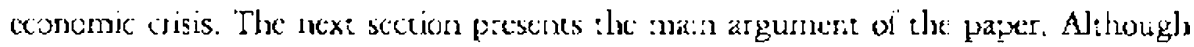
so:me problerns such as lack of pragmatism are of Conlucian origin, others, especially, the lack of acrointalility, transpaterry or truxt, canno: be artributed to confucian tradizion Indecd. I atgue that Confucian rradtrion: is rich in ideas and practires promoting accountabilizy, t:ansparency ard trase. Withcust fally understanding Confucian tradition, many scho'ars have been soo hasiy in associacing contempxrary Asian 
political culture with Confucianism, Hur:hermore, many t:adisional values and the

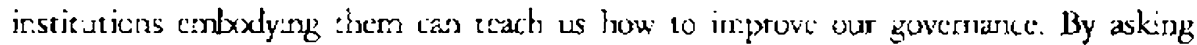
what are truly traditional Canfecian values and which among them are comparitle with demoxracy, wr can io a lor.p, way oward designing a system of Confucian governarce.

\section{KOREAN CULTURE FROM A COMPARATIVE PERSPECTIVE}

Let us define what culture is. Ho:stece (1\%)i) defines ciltrure as mental programming,

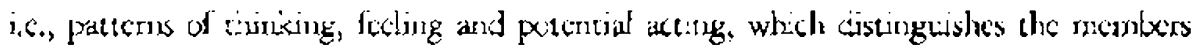

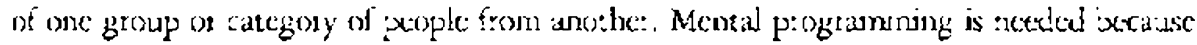
it he!ps groils solve their collective problems Accorsing to I fofstede, problems commor to all societies are (1) relation to auttority, (7) conception of seli, in paricicat, the relation between individual and soxiery and the individual's concept of masculinity and the expression of feelings, and (3) ways of dealing with confints, inciuding the control of aggression and the expression of feelirgs. Different sxieties have cifferent sclutions to these vroblems, which, in turn, repesent dimensions of their national cialture.

Consceucnty, there are fou: dinensions of nacional cultere, power distance index (PDI, iadividualism, masculinity, and uncertainty avoicance index (LAI). PDI

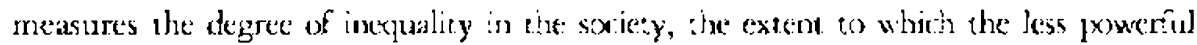
memixs of institutions ated oryazizations within a coumry expec: and arcept that power is unequally distributed Incivicualism, as opposer to collertivism, measures the exter. to which. members of a group place individial interes: ner grous interest. Shasculine oulures value success. money and material possessions, assertiveness and competit:on, whereas femirine clicurcs value caring fo: others, mairtaining warm perscoal relatiorships, solicanty with cthers, and tize quality of how life is lived. Lastly: uncertainty avcidance is tine exterit to which people in the sccicty want to avoid uncertair: sitidas:ons. People in kigh uncertaiaty avosdarce cultures prefer structuacd (it., strict iaws and noms) over unstnuterured environnents.

Ingletuar (1997) has done another major comparative study of ational culnures. According, to him, peojle's values ane shiffirg, from moxtern va'.ues to post-mediem values with inceeasing emphasis on the guality of life and scl-expression. To find support for his argument, he compares pecple's at:itudes toward five issues, 1) nost-materialist yalues, (2) subjective we'l-being, (3) in:erpersonal snust, (4) support for tevolution, and (5) support for refcrm.

lable 1 shows where Korea is located on the dimensions of national cultute that Hofs:ede and Inglehar: define. Compancs with Westcrn values, i.c., those of Norts America anc: Western Lurope, Kotcan value's are autheritarias, collectivise, and un certainty avoidung; differences are not is slgnifract en cther dimensions. Recent drbates on Asian values are largely consiste:ur with these stukies, since Asian values are usual'y cicfined in terms of colkerwe interests and respect for soder and hierarchy 
(Le ly 4). Comparative stucies of national cultures, however, co nor capriure one aspect of Asian culture, which is emphasis on education and learring.

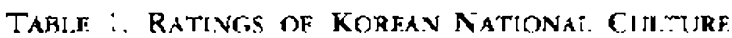

\begin{tabular}{|c|c|c|c|c|c|c|}
\hline $\begin{array}{c}\text { Dimensions of Culture } \\
\text { Countries }\end{array}$ & Korea & Japan & China & $\begin{array}{c}\text { Nortin } \\
\text { America }\end{array}$ & $\begin{array}{l}\text { Westcrn } \\
\text { Europle }\end{array}$ & $\begin{array}{c}\text { South } \\
\text { America }\end{array}$ \\
\hline $\mathrm{PDI}$ & 60 & $5 /$ & $58^{\circ}$ & $39: \vdots$ & 35.6 & 63.3 \\
\hline indivichlusalism & 18 & $4 t$ & 17 & $35: 5$ & $7 !$ & 26.6 \\
\hline Masculinity & 39 & 25 & $1,5^{*}$ & 57 & 42.9 & 4). 8 \\
\hline :IAI & 85 & 92 & $6)^{\circ}$ & 47 & 54.8 & $\overline{x i}$ \\
\hline Past-mietertid:sun & 18 & 25 & $?$ & 23.5 & 25.6 & 19.5 \\
\hline Suljecrim Woll fxing & 51 & $5 \%$ & 42 & 73 & 75.3 & 54.5 \\
\hline Inter:xemal liust & 34 & 42 & 60 & $\$ 1$ & 45.6 & 23.5 \\
\hline Suj]porting Revolutiun (\%) & 7 & $?$ & $?$ & G & í & $: 15$ \\
\hline Supportug knform (c\%) & 83 & $7:$ & bis & 7) & $2: 3$ & 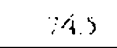 \\
\hline
\end{tabular}

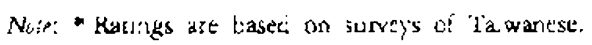

Sowres: Hofirede (15i)1); Inglehare (199\%).

\section{CIJITIJRE AND ECONOMIC AND POI.ITICAL PERFORMANCE}

Mainstream snidies about political cuiture have examined the ink between culrural characteristics and the development of democracy with a focus on the notion of democratic values and atcicudes (Diamond 1993). It has been argued that the develogment and mantenance of semocracy aeeds, or at least wculd be enhanced lyy, the presence of scrne cutural orientations sucs as moderation, couperation, bargaining, and accommodation amo:"g political clites. "These elements of policical chiture are needed to cope wirti ore of the cortra díemmals of deonerracy: to balance cleavage and corffic: with the need for conserstes"(Diamons: 1923). Fon chis point of view, what is netded is naltural te-orientarion, which promotes dentoxracy and as a result, contributes to entanced coromic performar.ce.

But it seerns that there are mote thas one way in which political culture can affect national economic pefformance. To snd out these othe: links, we mus understand how pciitical culrute affects actual geverrment policies. beconomists and game theorists offer their perspectives on the roe of culture. To scccetd, a suciety enust resolve ubiquitous collecsive aceior: problems calsed by the existe:ce of ancertainty and teansaerion costs. When there is toc much ancertaitaly, cormal institurions are not comprehensive or flexible enough to solve collective actior. prollems. To cope with a high level of urcertainity or unforeseen contingencies, a scrie:y or organization has to come up with a loose set of norms and 'xilie's, called culture. According to this perspertive, the 
role of culture is instrumental and finctional; it is desigsed to promote efficient transactous. A related, bu: slightly different idea is viewing culture as foxal points, natural reference peints arounc which accors expectaticns converge. When there is more than onc mutually bencficial agteemetu and ac:ors cannot decide whith one to choose, they have to coordinate with cach other. When explicir coordination is urfeasible or prohibitively expensive, it melps to have focal points, soward which actors will gravitate without explicit communica:ion. According to this perspective, the role of culture in promcting effucient iansactions is limited to gading the actors expec:ations; culture does nor change the incentive strucr.re of relationships. Seen this way, political culcure conrributes to the choice of be:ter public policiss by helpng folitical arors resolve their collective actior: probicins.

What really mater to natic:al periormance, howevet, may be not cultural ciat

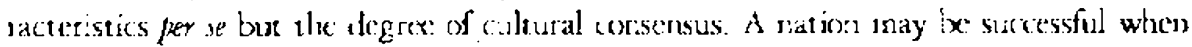
its culvure is cohorent and adapranle, enabling it to define and attain its goals, and when there is rhe least distance berween the prevailing alture and the forma. ni.es and regularions of its institurions. 1 When a country has conflicrirg culurual values with ore set dominating aciual practires and the orhe: shapirg the formal rules and regulaticns, its culture is inconerent and inconsistent, it tails to perform successfully. The study of culoue has beer. experiencing a tenaissance sunce the publication of lrust by Franc:s Fuklyama. Under the assinnotion that a sustaiacd economy regiures a particular form of industrial urganization, i a, the preserce of large-scale, profe ssimally managed, "spomaxeously formed," provate firms, Fikuyana argues inat Jow-t:us: socicties in which relationships are bascri on fimily and kinshign anon support surt. organizations 'xerause they canno: mobilize recessary rosources. Folowing Fukuyama, Putran: emphasizes the ro's of trust, which he calls social capital, in enhancing demoxratic governance and economic peformance. He fincs the evidence in Italy where differences in social capital, as manifesied in levels of civic engagement, explain the variations ir eccnomic anc pclitical perfermance across regions. Both rukiyama and Purnam assume that how well a soc:ety perouns depends on the success of iner-group cooperation and coordinaion and that the sole of culture is to faciliane such collective actions.

In the case of Korea, con, culture has ofter been cited as a rriciral factur in arcolinting :or its ceviopmen: pa:h. Bux it is dificule $r i$ isolate the efferts of culture. A.thought it is tnde that Korean national culture is clearly disrinct from these of otner narions, we do not know a: that level of agg:egarior. which aspects of Korean oulture facilicate of impede its desclopment. Dianord (1999). for example, argues that the public perception of democratic legit:macy is the key dimension of political culture fronoting democratic stabliny and consuludaton. For Korea, he finds that peuple's support tor democrecy has grown ove: time. It is also founc: that exomomic and other

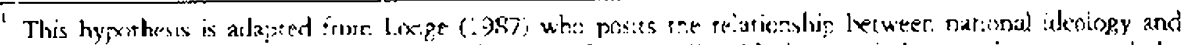
corpextitiveness ir. rerms of the distance xeru een :he zrevalling ideology ano the actuai practices ot the cov::ily's iss:-iutiocis.
} 
performance rariables have had lirtle effects on public sapport for democracy. Diamond, however, overlooks o: her cutural cerrelates of democracy that are celevant for explaing the perfonmance of demextacy, e.g., how effective policymaking :acesses are. Since be is interested in understanding the stability of new demax:acics, he focuses on the: perceprion of democratic legirimary, which he believes is one of the most significant deteminants of democtatir stahility.

However, it is no: cleat whethe: support for cemoctacy is even the tes: predictor of democraric strability in new demorracies. In the long rina, demioracy has to perform to sustain itself. If certain values and attitudes (s:ach as tolerance, sust and accommodation) are pre-requisites for good densocratic periormance, it is important to ask wixether those values are preset: in: new denaxtacies. Moreorer, democratic ingitinaky may be an outcome or componem of dentoratic corsolidation tahler shan its determinant

Another problem with an exclusive focus on the putilic support for demoxraty is that although people suppor deroncary in principie, their support for specific democraric acts or practices may be weak. Fo: example, the puialic desires and demands stronp, leaders. Ever. weake: ate pople's democratic values; Korean people remain 'argely authortatian, collectivist and distrustrul. As a resialt, people hold "negative" expectations about orhers' betavior. : am: confident shat most Koreans wll say no if they are asked

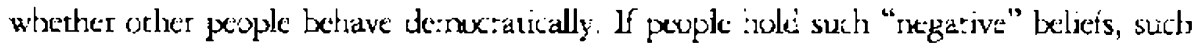
belicfs can be self-sulfilling expectations and people wil" not behave demox ratically, expecting that othen will not reciprexate.

Altrnomgle there are no systemic data, is apixars that the nucst salient seatures of conte:nporary Korean political nalure are authoritarianism and a lack of political pragratism. First, major political actors, inclucing the executive leadership, the bureaucracy, the ruling. New Kored Party, and some top political organizarions, did not completely shec their authoritarian ways. That is, they we:e ofter. re'uctant to build a consensis through the democratic process. President Kim Yojng Sam, for example, was widely cricicized as a "ivilian dictator." Ihe public, for its part, was

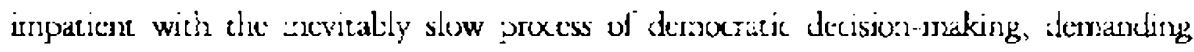
quick sojutions anc' strong leadership. This peference fer "quick and efficiert" resolution. of disputes, which is on.y posstble ander authoritarianism, is confirmed by various puthlic opinion surveys. Shin (I998), for example, finds that only 9 percent of Korean voress are what he cals :cpresencative demorars (i.t., those who endorse democratic iasticutions and rejec: authoritarian so'utions). Almose a half of the respondents (49) percert) support democratic instisutions but refuse to :eject authoritariar solutions füy. Others are streag or weak supporters of authoritarianim.

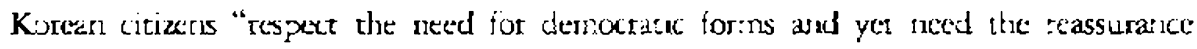

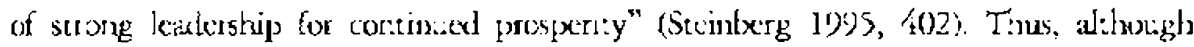
Koreans sujpuxst democracy in prociple, their suppourt fer demox rary in astion is lukewarm at heser.

Sxond Korean cirizens have been slow :0 adom the values and attitudes neccssary 
Sor democratic dispure settlement such as pragmatism, a display of trust and tolerance, and axliers in equaluty and rignis. ${ }^{2}$ On the basis of survey data, Han and Euh (1984) b.assitiex only 30 percerne of Korean citizens as having both modern social values and demuxatic values and attitudes (display of enw: and colerance toward others and beliefs in cepulity and :ighrs). Kotcan ritizens are also :tored for their willingness :o protest, rashe: than looking for a negotiaced serelement to a politisal dispuste. A Cunfucian emphasis on morality may be anotiner reason why political artors lack paagmarism. As aoted by $\operatorname{Kin}$ (1988), politıal disputes are of ten tramed anc depicted as cnatroversies oier opposing moral principles, with each party adhering rigidly to its abstanct causes and rejexting compromse for Eear of "losing face." Cultura barriers to a negotiated settlentent of political disputes were particularly severe when the disputes featured two serong interest groups. 'lthis is consis:ent with Helgesen is (1998, 257-58) observation that Korears' willingress :o trust and coopera:e depends on whealuer they interan with an :n grolip or an sut-group. Policical disperass involving two out groups ran rarely be resolved througn negotiation. Iortzor:al coordination and cooperation in a hierarchiral sociery is also difinit 3 When the relacionship berween wow groups or individuals is not verica"y ordered, or when the old hera-chiral relationship breaks dowr. as a result or political charge, a cooperarive relationship becomes ha:der to maincain.

Mo (2001) argues inat political chitu:e has been associated with the persistent problem of policy gridlock uncer democracy. The most re.ling teanple of the regarive role of political culture is the ccor:onuc crisis of 19);. Policy gatdloxk over comonk ré:om had lasted for wer :0 years lefore the erisis and one car: say that tre gridlock

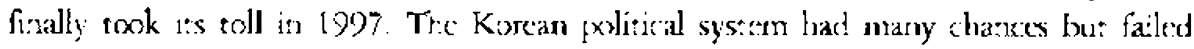
to carry out long over-she eronnmic reforms.

There ane many cases of gricy griciock because of the political culture and weak democratic institutions, which are mosi pronouned in the legislative process. First, the system of legislative bargaining is not firmly established. Despite its constitutional naandate, the National Assembly continues to be subord ate to the executive sranch ir: the policymaking p:ocess.' Nsther does the bereacracy provide a itable me-

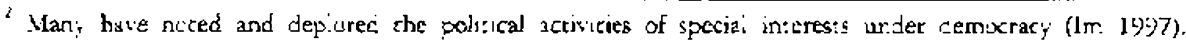

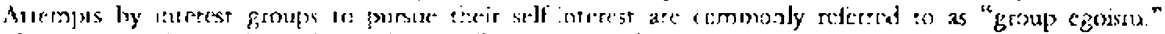

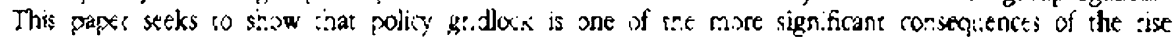

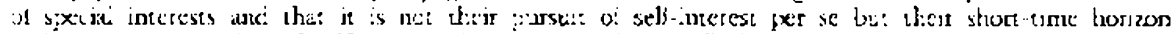

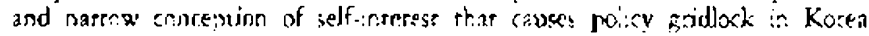

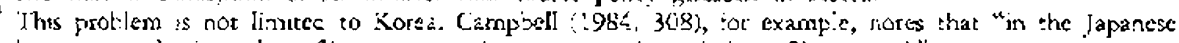

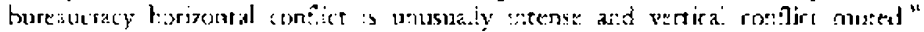

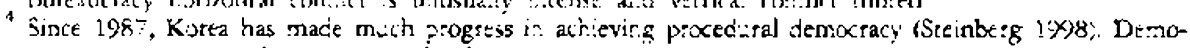

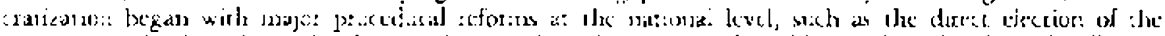

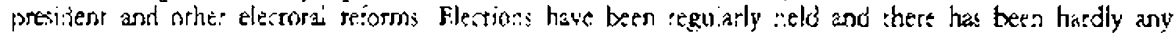

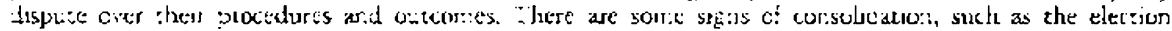

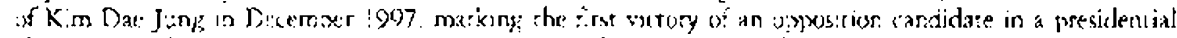
tect:un. As this zape: expains, huweve: Kuxtar, denocray is stï- mazuriag.

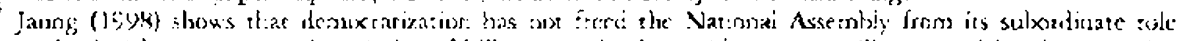

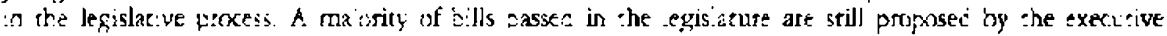
tratisi.?.
} 
chan:sm of interest untermediation. As a resuit, dispiting parties do no: have a piace is. which so negciare. A though the government has empleyec independent commissions to build social consensus or. labor and financial rctorms, they have been ad hoc and termporary and, as such, cinnot substitute for the legislanure as aienas in which to negoriate

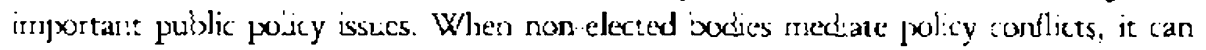
aggravate policy gridlox becaust there is no obvious way iv decide whicis side has majority support and their decisiens are not accejoced as legitimate.

Second, when ir comes time to maxe derisions, ir:ormal rules, such as constraints on rajority rule or the consensus norm in the Nationa Assembly, often take precedenre over Sormal rules. Under cer:ain conditic os, the rajority pa: 3 is prevented from exercising its majorty in the National Assembly. ${ }^{6}$ In at least awC reform episodes, the lexor reform of 1996 and the finarcial reform. of 199 ?, the culing parry laci to withdraw its propesals if: the lace of strong uppositics: even thungh it ad a suld inajonty in: the National Assembly.

Mo (2001) is an effor: to demonstrate llee effeces of prylitica. nilenge on spexific poliry ourcomes in Korca. Previous studies of political culture in Korea and elsewhere have focused on the commarisility berween polinica: milure and liberal demoxracy, but not on the cole of culture in pclicymaking process (Pye :985; I jiarnond 1993). Ir. inying to isolate the tole of cult:ure, Mo (2001) presents a way to think axour the poicymaking processes of Korea during the period of democratization.

\section{THE RELATIONSHIP BETWEEN TRADITIONAL AND MODERN VALIES}

As I have argurd, rhere am aultural harriers to reftrient dispute sstelement. Uriess they are elininated, Korear: demorracy will continue to suffer fron policy gridlock. It is srraightonvard to see why negotiation may not we the preferred way co collective cecis:on-maxing in Corfucian cul-zure. First, a negotiation situation implies the existence of a cer:ain degree of equality between the paries in that one party carnot stonply rrpose her will ca the orher. 'lherefore, there would be relatively few regotiation situa:ions in au:horitarian cul:ures because nost retationships are veri:cal'y urdered. In those sucketies, aullority: raciner thass negotiation, is used a sette dispuses. Second, Confucian lcaders are supposed to lead by way of rexir virtue anci if they find chersetves in a negoriarion sioution with their followers, they would be atimitring their own failings. Thiad, Confucians, who ate supposed so seek moral perétion, wisuld not bx: comfortable with negotiation s:ruations in. which they may have on be

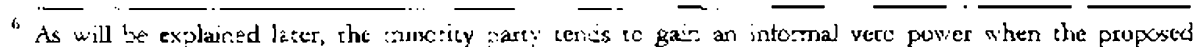

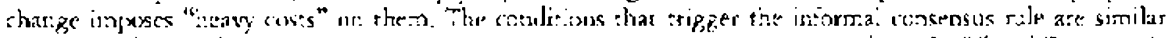
to trost inde: wh.ch Japanese opposi:ion parties were as.e tc wir. compromses fom the Liberal Demoraric

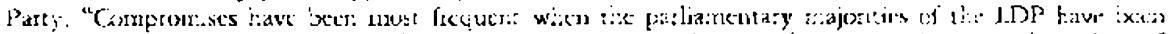
slinmest and whe: the issies have 'pen gene-aring the mess heat in the press and ameng the citizenry" (Per:yjed 19\%\%, 1:).
} 
calculating (ef personal interests) and maripulating (of their intentions). Given these, it is placisilde that mukh of the surrent diffeculty with negotiation originates from Confucianism.

However, it is one thing to blame Confucianism for a lack of pragmatism and it is another so dismiss Confician values as irmelevan? to modern democratic governance. It would be a gross misrepresertation of Confucianisn if one associates it with crony

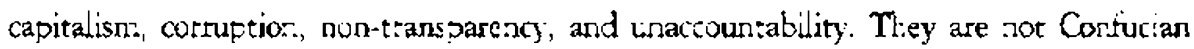
values and nor are they inevitable consequences of Confucian values. Nor only were transpareacy, accountability, and freedorr of speech he'd up as polirical ideas by Confucians, mary political teacers sucessiuly promoted and protected them. The demox ratic nature of Confuciarism also inclucies tine ideas of popular sovercignty and resporsiveness to public opinion or public consensus.

\section{Transparency and Accoumability}

Accountability is one of the aecessary conditions for gonc goverranke. For a long time, political theorsts have thought that the key to good governance is tc keep pcrer urder concro. "In traming a governmenthe grea: difficulty lies in this: you must first enable the gove:nment to contro' the governed: ard in the next place oblige te to control itself." Ai the conceptial level, accouritability indicares the cegrec to which powes is kept under control, domesticatece or subjec: to the rule of law. In terms of institutions, ancountalility tescriles a retaimship trerween accoumtable and acrournting parties, i.c., the degree to whith accountable parries are ascountable of arcounting parties.

"A is accoliatable to $B$ winer. A s obliged 0 inform $B$ about A's (past and run-e) ac:ions ard decisions, to justify them, and to suffer punishment in the case of eventual misconducts" (Scinedier 1999, I7). Accountable agents have to possess the capaciry to demand public ofticials to inform and explain their activitues anc to impose sanctions on office holkters who violaie cerrain :ules of conduct.

Types of accountability vary according 10 its standards and sources. Different

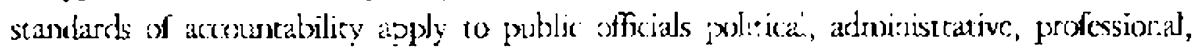
fuxamcial, moral, egal, and constitutiona'. O'Dunne.. (1999) makcs a distincticn leatween verical and horizontal axcourtahiliry, depending on the hicracicical relationship berween accounting and accountable agents. If accolinting agents holc agencies of equal powet or position accountable, they are said to be exercising horizortal accouncability. A system of checks and balances among the tarte branches of government is an exarnole of honizontal accountability. Agen:s o: horizental accouncability also include ombudsmen, auditurs, accolating elfices and antu-correption commissions within the

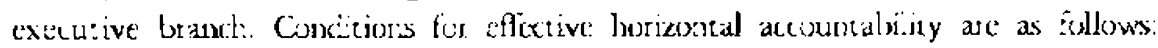

1. The cxistence of vertical accounrability.

2. The existerce of multiple accusring agencies. Effecrive horizontal accounability 
is nou the :rocluct of isonated agencies but of retworks of agencies that anciude at their tep courts committed to such accourability.

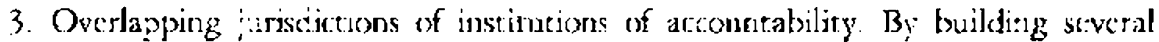
streng powers that partially intn:de on carh orher, we can enhance the aluonomy of each of them with respect to what would have resulres from a simple separation of such pxwers.

4. The accountirg party must independent from the accouncab'e party in all decisions that concer. ins field of competence.

5. Recursive and reciorocal accountability accounting agents "check and balance" or are accournable to each.

Transparency and accountabili:y are rot alien to Confucian cultute. Agents of horizontal accountaibility, in particulaz, were considered as essential to the success of Confician governance. A good example is the Cersorate of the Chosur. Dynasty. a Confucian embociment of horizon:al accountability. The Censorate ccosisted of three cersoring organs, the Ofice of the Inspector-Gencral :OIG), the Offec of the Censer- General (OCG, and the Office of Special Courselors (OSC). Ihe Sarasia, as the thex were known, were cesignes to prever: alsuses in the exencist of political

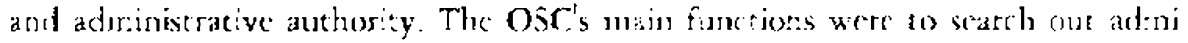
nestrative ard legal precedents, write major sate doxuments and advise the king on piblic affais.

Arrong the three, the OIG and the OCG, which came is be knowr as taegar or Censcrate, represented the swc main ager.s of accountajility within the government. Officially, the OIG was chargec with "critcizing public pcicy, sc:utinizing the ccnduct of the officialdom, rec:ityirg motes, redressing fublic woongs, and preventing

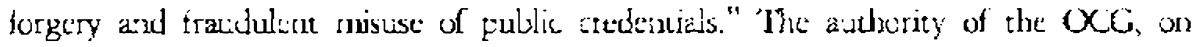
the other hand, was to offer renorstranee to tixe king and to lexge complants against office bolders. The sestraint on the conduet of the king himself by the OCG was perhays the most innovative feature of Chosun's structute of horizontal accountability. On paper, there were clear differences in the autbority of the OIS and the OC.r. The:

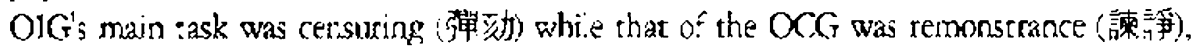
i.e., evaluating the 'sings conduct. But their jurisdictions overlapped is practice, and it is more accurate to say that the OIG and the OCG worked together to monitor and cyersighe "all aspects of rcyal, oficia, popular (principa'ly yangban) conduct and irures."

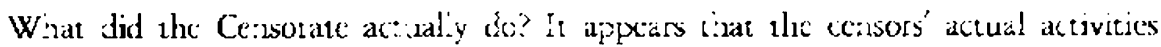
were much oroader than the formal desctipticns of their anthorty indicate. Acoording

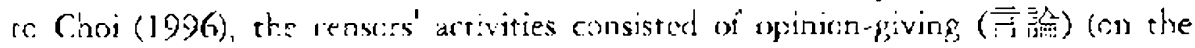
king's condurt, censure, policy choice, and offacial appoirtments), fasticiparion in

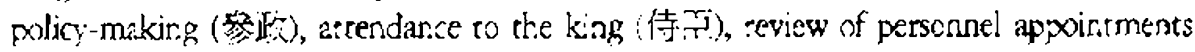

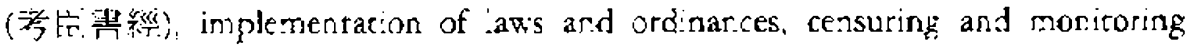

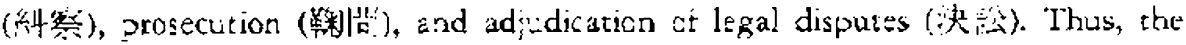


cesisors were not wiy judical and auditing agents (judges, prosecusors, and auditers) but also voices of dissent and opyestrion ( opposition pasties ir: madern cemaxracies. This aspert of the Censorate reflected a strong Confuciar belief that the king s'onuld ancourage open discussion and criticism withis, the goverament. At the sane time; t-e censors also acted as policy advisors ard counselc:s by offering opinions, recummenciations and guidance on the basis of the:r knowiledge of history and Conficien pialosophy to the king and high oficials.

1 it:gue that the censoring organs were accouncing agents in a modern sense becaust racy could subject public officials to the threat of sanc:ans, viluge then to conduct their deties in trarispazene ways, and force then to explain or justify their

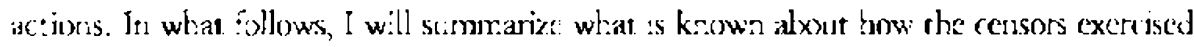
these powcrs of information, justification and enforcement.

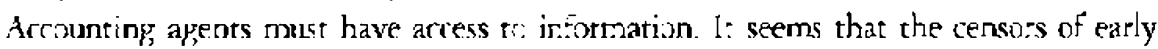
Chosun had the foilowing sources of information: First, they participated in the fo:macive stage of folicy-naking by attending Royal Lecture sessions. Even; OSC counselor was a nember of the Office of Royal Lectures. The Censcrate was allowed to join the morning and afternown sessons. The Censorate also insisted on participating

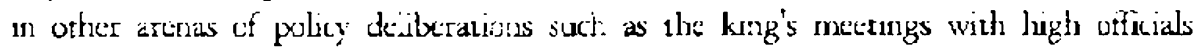

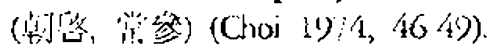

Sercost, important prolicy and appoin:ment dersions were subjert to formal review by the Censonate. All appois:tments to civi! and malitary posts below the Fourth Rank were to bo approved by the Censorare. "In arcordance with a procediare known as sogyong, a dxumen: bearing the name, lineage, ard caree: data of each such appoinnec was subritted to the Censorate for erdorsement, and if the Censorare officials failed to give their apprcval wi:hir. fify cays, ise appointment would be rescinded" (Wagner 19\%, 15!. More impo:tan:ly, Censo:ate remens were required before promalgating new and anended law's. I lowever, it is doubtal that this review amountes to a ommal veto because the Censorate intervened afier the hing abready aporoved the new laws that were legislated by 1 he State Commil. At this srage of legislative process, the Corsorate may have simply screened the lar.ponge of new laws for 'ega' rensistency and enforceability instead of delitxrating their subsance.

The third source of information was rhe reporeng of acts of official misconduct :0 the Censcrare, typically shrough memorials to the king, jy those pitho suffered from or wirnessed them. Other sar. these ex ante sources of intormaticn, it is not clear whether tiney hac ex pos: capabisties to gain informasion through. regular anci ir:egular audits. 'liney nay have relied mainly on memcrials sent to the kug even though they may not have liad access to them kefose teakting the king. Neiclue is dear whether

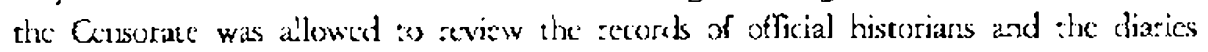
of government agerrics.

The pxiwe: of justification was inplicit in the way that the censors went about "prosecuting offenders." The itrse thing that tine censors wou'd to was to make accusations. The accused parry woulc then be corced so defend ioself tc the king 
against tate charges made by the Censolate. This way, the cersors wetc able to demand and reverve explanations.

The next question is whether or not the Censorate was able to excrcise or enforre their authorty. It appears tha: the censoms had many opportunities to present their views to the kirg. They could offer temonstrance during Rcyal Lecture sessions. They nere alsc invited to imporant meetings convened by the king. The regular channel of communication to the ki:g was direct reporing (怒言) in writing (上流交) or verbally. Ihe Censoraze could recort twice a day. in times of emergency, they cou'd do so as rrany uines as accessazy.

The rain instrument of punishment lhat rite censoring socies possessed was cemsuring. Censures we:e scommended to the king ayanse of:icials why commined risconduct and broke laws. In the recommendarions, the censers not only explained tise nature of infrarticn and misconduct but a.so suggested specific neasures of punishmant. The king, upon rece:ving a censure request, cecicied whether or not to prosecure the accused(s). Inierestingly, the king rarely :ollcwed consure recomrenciaticns. Chung (1994) reports that the acceprance rate (which is defined as the proporion of censure cecommenciaions that we:e fully or parrially accepted by the king! was orly :4.1 percers diring the rcign of xing Songjong. More often than aut, the king: es:xcially, King Scje: tred to suppress the censos by comploying a varety

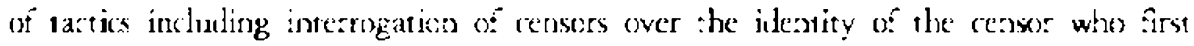
conceived and suggested the censure (Ching i994). Chung couriors against a simple irserpeptarion of the low success ate of cens.ure petitions that the Censcrare was ineffective o: nct influential. First, it sook a mumber of cersures (cvet one bundred in the case of Han Myoresthui) to "aail" a rarger. Therefore, we have to ask how uften the Censorate eventually succeedec once they set their targes. Second, somewhat counter-intuitively, the low suciess ra:e may incicate that the censorate was being faithfil to their mandare. Reme:nuber that the sensuring bodics were designed to "tikek and badance" the king, so they were expected to ofer recormendations tiat the king did loo like.

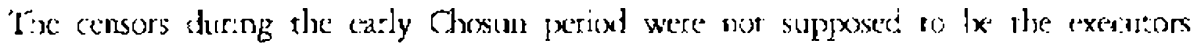
of the king's will. If the rensors had s:mp'y followed the king's wishes, the arceptante rate would ave been much higher.

So far, I have discussed shy I thisic that the censoring orgass in the early Choun. perind were indeed institurions of horizontid accountavility according to the definitions of madern cemocratic theory. The reascn is that the Censorate fulf llec the three essertial functions of accourting agencies, information, justitication and entorcement. In my vew, however, what is metesting about ihe Censorate is ror that

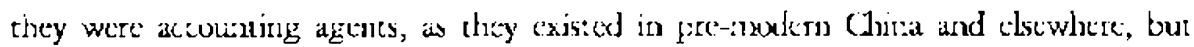
that they were well or even optirsally resigned sorefective horizontal accountabilety. I say this herause the censorang ins:irurions of the Chosin ciynasty seem 0 have sarisficd most, if not all, of the strict conditions for effective horizentai accounability that we impose on modern poijarchies: (1) the autonomy of accounting agencies, (2) the existence of mulciple accoun:ing agencies, $(3)$ the preserce of over-lapping jurisdictions 
arrong the accounting agencies, (4) recinoxal accountability, anci (5) the existence of ver:iral accountability (s:ch as elertorai discipline)

When designing a system of horizontal arcounzability, we have co solve two proble:ss. First, we have to create acccunting agencies that are suficiently powertul or autononnous to do their ;ob. The seconc.; more difficule p:oblem is a second-orcer arcour:ablity issie, ramely, how to hold accounting agercies themselves accourtabie. Let's first rake on the easie: issue of the rwc. Since the censors main rargets were high ofticials and slic king, we have to meestagatc what kins of mechanisns were un

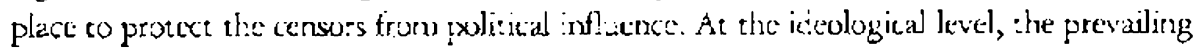
moral phïosophy of Corfucianism with its strongenphasis on mo:al rect:anke and historical example provicted the raison d'ete for the censoring system. As leng as Confucianism remained a state idenogy, thare was always geing to ixe a cerair level of support for it. To xe implementec effertively, however, the :dea of strong arcounting aguacies has to be embodied in spectic ins:trutions and pracices and more importantly, has to $x$ polit:cally suppcred by a sufficient number of impcrast stakeholders in the government.

A nimber of porective devices were used to ensure the automeny of tile Cerworase.

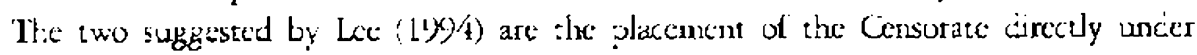
the k:ng, outside the formal ine of adrinistration, and the bar on the censors boiding a concurres: position ixciuse of poss ble cor:flicts of irecrests In addition,

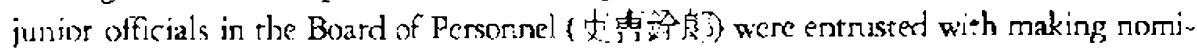
na:ions fo: Censcrate pesitions, maxing the censors auroromous of the high-rankings officials that they were slipposed to critcize. Political .eadens at the tinze did nor want the censors to become depencent on the personnel uficials and gave the censors a limited vero over personal decisions. Ir early Chosun, the pessornel offictals and the censors coopeated with each orher to check anc balance ti:e power of meril subjects anc other high officials.

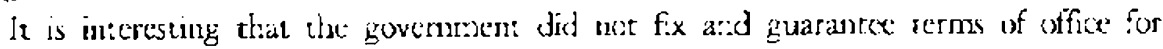
the censo-s, which would have belped enhance thes index andence. Reroeds show shat rhere was a high dogere of tisncver in the Censomate. Bust the censors typically receivad promotion after the end of thein tenuse and wore not ass:zmed to provincial positions immediarely atter leaving the Cersorate (Cho: 19:4). Borh of these m.easures were intended to prevent the lise of cemotio.ss against the cer.sors as a way of influencing their decisions. The censors wee a so exen:pted from si-2nnial pertormance evaluations, which were required to: other offeials. It is not clear is what excent the cersoring argans were Sinancially anciependent, whuch would be a plausiale indicator cf their independence.

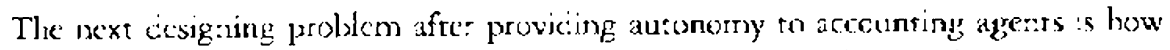
to kcep them undes control and holk then accountalyle. As if following the prescriprions of modern democratic theory, the designets of the Censorate set up multiple accounting agents, madc their urisdicions orer-ap and allowed them to monitor ore another, thus crearing a system of raciproca accountasility, As explained above, the Chosun 
government had thee cersuring organs, wh:th were accountirg agencies. Moreover, individual censors enjoyed such a degeer of independence that we can say that each coe of therr. was an arcounting agency in his own right. The censors censured not cnly other censuring agencies but also their own colleagues and even supericrs. The censors' jurisdictiors also cverlapped, much mo:e thar. the law provided. The only formal area of overapping between the pariscictions of the $O . G$ and the OCG was the power to revew xersonnel and leyislative derisions. But their jurisdictional boundaries converged in practice, especially in the areas of remoustenuce and censurng. The convergence of urisdicains, in turn, allowed lae cersoring crgars to hold one ano:her arcountrable:

The weakest 'ink in Chosun system of horizonal accountability was: of course, the absence of vertical accountability. That is, people had virtually ro ability to keep political leaders accouratabie. The only oirside restraints or. the kirg came from the threat of revolt anc coup.

Institutiocal explanations of the effectiveness of the Censorate can be criticized on two grounds. First, institlitions art bincing as long as there is a sufficient evel of policical support for the:x. According :o tius power-orented school of nought, we have to investigate the aignmert of political interests that supported the Censurate if wo want to oxplain lice carly success of the Censorate. Durneg the carly Closum pericxl, there were wo dite groups competine fot power, meri: sujojects (and royal marriage

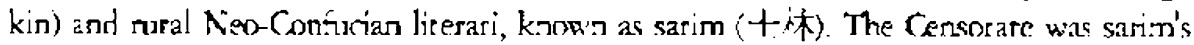
main platform for chal'eng,ng the dominance of merit subjects. At the time tine king had incentives to promote sarim and thus, the Censorate becalise he needed to counter-balance the mesit subjects. 'Therefore, a power.s] alliaze berween the king and arim was the politica' foundation of the Censo:ate. When this allance cinanged over tirse, so did the indiutese of the Censorate. When the king did not feel that tise Censora:e scrved his interests, ine was willing to punsis and ever: purge ile ceisors as Yonsa: gun and King (Jungisng did on four differem occasions. The Censorate's thlinate loss of effectiveress may have come when sarm themselves lost interest ir. horizontal acrountability after finally wianing power curing the reign of King, Sonjo.

The second line of criticism.s woulc focus on the accuracy of historical faces. The Censorate. Eor example, may aot have worked as they we:e supposed to. From the very jeginning of the dynasty, thete were constant criticisms of the censors for :naking

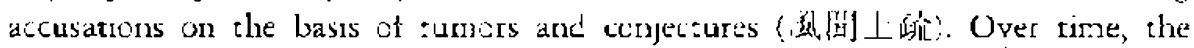
censcring bodies becane increasingly natclean and partisan. By tee $18^{\text {it }}$ century, the abuse atad decline of tix Cersornte was so scrious that Clourag Yak Yong opeoly s.1pporred its atuliaison

Despite these resenations, the experience with the Censcrate shows that the icie:s of transparency and accountability are classic Contucian values and that :xolitical leaters o: the Chosin dynasry designed it with ar elaborate and surprisingly "rodern" construce. 


\section{Trast and Mutual Aid Organizations}

Confucian scholars also ecognizec the importarce of rommurity organizations to effectve governance. It was (hu $\mathrm{His}$ in the 12 cenrury whe incorporaied the p-inciple of voluatary cooperation into cornmunity structures (De Bary 1998). Based on the community corapas: of Lu Dajun in the $11^{\text {:h }}$ century, Chu formulated four princigles of cormminity build:ag: (1) muitual encouragement in the ferformance of worty cecds; (2) murual admonizion in the correction of errors and failings, 3)

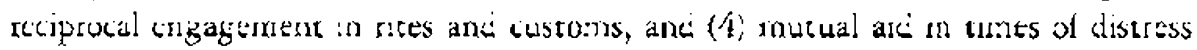
ared :nisfortune. The key aims of this compact were to establish staible self rughiating

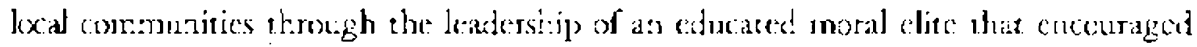
self-discipline, rout:al respert anc: assistance, voluncary efforts, and joine ritual to provide for the needs of the commurity as a whole.

During the Chungchong reign (:506-4h) of tize Chosun dysasty, the guverament is:rocuced tire commurity conpaci systen, called byangrak, from Sung China. Loxal yingban elites either directly acopted the Cht: case us cne of rite Korean versions in organizirg their own communities into a self-governiag corporate structure. The certeal government eccegnized theie leadershy in le maintenance of comminuty order

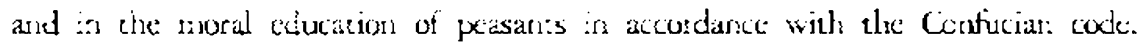

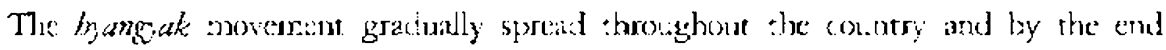

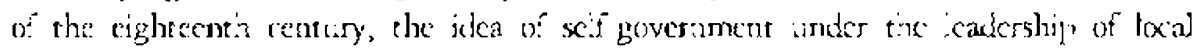
elires became firmly established. Fven in those hamle:s with a resident ;angion family, peasants organized themselves into a copcuate unit by aciopting one of the oxai codes.

\section{A Government for the People}

Popular sovereignty is ano:her idea that Confuciars ceveoped and practiced. Accurding to Meng-lan, tize king is the son of heaven, and leaven lestowed on its son a mandate of provide goox: geverment, that is, to provide goxed for the people.

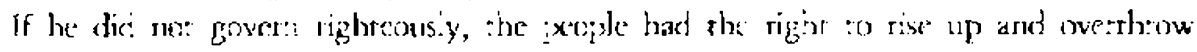
h:s grovernment in the ziune of heaver. Mong-tzu even iustified regricie, saying that once a king loses the mandace of heaven he is no 'onger worthy of his subjects' loyany. The ancient Chinese philosophy of “people-based politios" (民柢政治) teaches that the will of people is the wil. of heaver. 'Therefore, one can say that Cortucians believed in a goveroment for the pesple, if no: by or of the people.

\section{Public Conserisus and policymaking}

Ar unexpores territory in sixe snury of governanes is the role of policy advire in improving the eadity of goverance. Ideas are a concels that best aptures the effect o: policy advice on policy outcomes. Ideas, along whth interests and insticutions, are the mair deterninants of policy choice. Iceas affect wolicy outcomes is. at leas: three 
ways. Firse, policymakers look co aut with mearing and plipose, and ideas define

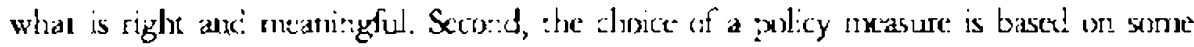
understarding of cause and effect, and icicas explain the calsal relationships among the phenomena affecter by policy choire. Isstly, ideas ar: as focal points. Once ideas are accepted, they inflience cutcomes primarily as points of reference or anchors around which actors' expectations converge. This explains why certain ideas remain in:luentia even after their original rurmative and positive appeal has weakered considerably.

Discourse on policy advice ias a long radition in East Asia, lr. fact, Confucian philosopliy was fourdec on the idea of good governance based on good advice. Ihe roie ef the scholas-bureaucrat was esse:sially :o give policy advice, $\ldots . t$. , to advise and

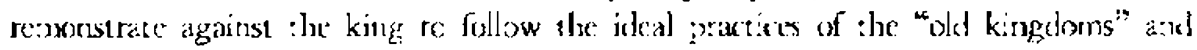
tearhings from classical Corfuxian texts. Atemative soures of poliry advice are also familiar to Confucian tradition. Diring the Chxiln periad (1392 - 1905) of Korea, government officials were not the coly source of policy advice; Confucian sciolars out of office, who nere either preparing to er.ter the bureacicracy o: educating students in loxal schools, played a leading ro.e in shaping public opinion cn majo: poicy isslies. Pelicymaisers of the (hosun cinas:y firmly believed in the politicis af Sarm (1 th), accorcing to which pubic poley was euded by public opinion in the firm of official conserisus.

\section{MERGING OF NFW AND OLD}

In many pays, participants in the Asiar. values debate have taiked past each other. Proponenes o: Asian values like lew Kwan Yew are guilty of denying the democratic traditions of Asia, while their crittes like Kirr. Dae Jung make a mustake of denying the existence of undemocrasic valies and atricudes in contcroporary and tracitional Asian culeures. Ilx dejatc now has :o move forward in now directions.

Firs: we have (o) accent the destiny of de:nocrary and ask which contermulary Asian values and a:tirudes ohsmet the zerformance of Asian demoracies. Asians have to improve their demoxacies, regardless of atecher they have democratic traditions or nce. In the case of Korea, I argue, it is the prevailing (anti' negotiation culture that has proved mose damaging to the peformance of Kortan derrocracy.

Seconc, Asiars should lcok for their own model of cemocracy. Before importing W'estern institutions, they shoud be subjest to a compatibility test, 1.e., whether tiey are compatible with. local political cul:urs. It should be noted ibat Westem liberat demoracy is no: the only model of denocsacy and there are a wide vatety of sterow rati systems. For models of Asian governane, ene : As I showed, there have bean many ; xolitial instimtions in Asia that are demorratic as well as grourided on traditional Asian values. 


\section{REFERENCES}

Camplecl', Jomn Csrighton. :98/4 "Policy Conflict and its Resollation witum the Governaxut Systen." In Comfict ir Japsm, eds. Fllis S. Krauss, Thomas P. Rohien, and Pa:ricia G. Steinhoff. Honolulu: University of Hawaid Press

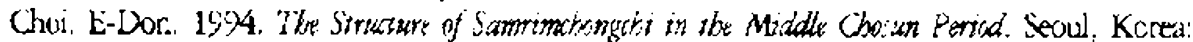
li Clis Kak.

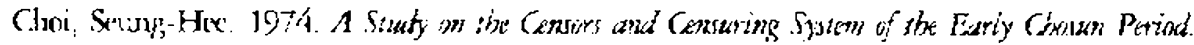
Seoul, Kriea: Serul Varional Uriversity

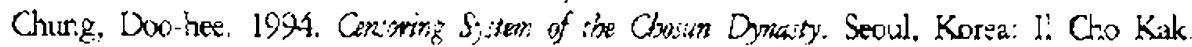
De Bars, 'Ihecdors. 1998. Asian Values and Human Righis: A Confuian Communitarian perspecitive. Cambridge, NA: Havard Un:versicy Press.

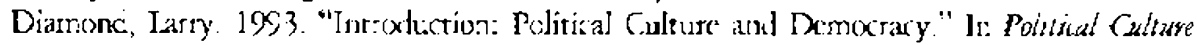
and Demaracy in Davioping Cimtrier, ed. Iary Damonc. Pouldar, CO.: I.ynne Reinner Puslishers.

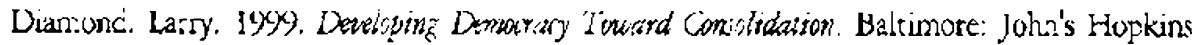
U:uversiry Press.

Fukuyama. Trancis. 1905. Tnut: The Soxial Virtues und the Crustion of Protperity New York. NY: Free Press.

Helgesen. Geir. 1998. Demorac, and Authority in Komai. New York; St, Martın Press.

Han, Bae lio and Sooyoung livin. -98: Komean Polizical Culture. Senu: B:p Mur Sa. (In. Kurean)

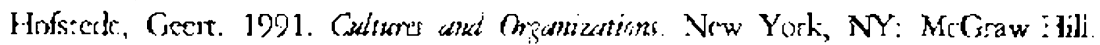

Im, Hycg Baek. 195?. "Sorsoldidaticn of Korean Democrary: Assessments anc: Proxperts." In Demiscratization and Refarm in Siath Korea, ed. bae Ho Hahr. Seovl Korea: The Stiong Institute.

Iaglehar:, Ronald. :99?. Modemization and Postmolemization. Princeon, NJ: Princecun Jiniversity Press.

Jaung, Hom 2000. "Instinutionai Reform and Demoxratic Consolidaion in Korea: Elections and Political Partes." In Insizuticnai Rfinem and Demoratic Coniolifution in Koted, eds. Larry Diannord and Sivin Do Ci.j. Sianford, CA.:H lowver Institution Press.

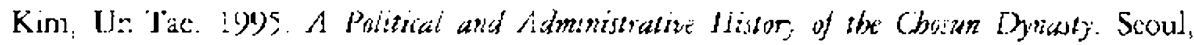
Kurea: Paik Young Sit.

Kim, Dae Jung. 1954. "Is Culcure Desriny: The Nyth of Asias Anti-Demincraric Values." Foreign Affars (November:December): 189-1)4.

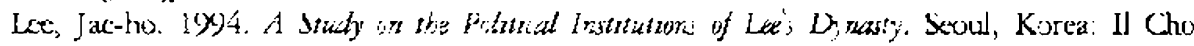
Kàk.

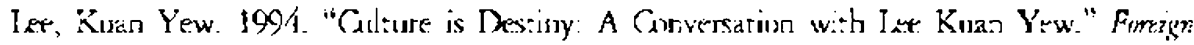
Afari: (March-Jure): 109-126.

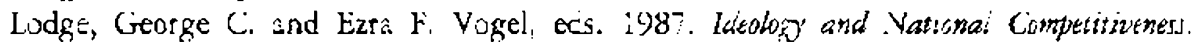
Cannbridge, MA. Hevarsi Linersity Press.

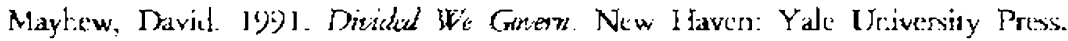

Mo, Jongryn. 2001. "Political Culnure and I egislative Gricllock: Politics of Econcmic Rệron ir. Pre-Crisis Korea." Comparative Paligical Studies, 34 (5): 467-92.

O'Doneil, Guilemo. I $y$ y). "Horizontai Accourability in New Lemocracies." In The SelfKe:traning State: Powtr and Accientabiliy; in New Demioraties, eds Ardreis Scheciler, 


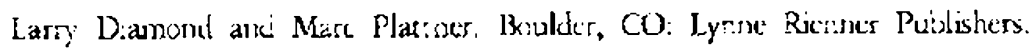

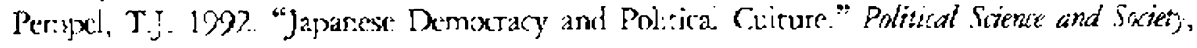
2.5: $5-12$.

Putzarn, Rober. D. 1999. "What Máxes Democaty Wo-k? (Inportance of a Vital Givic Life)" Natichal Civit Rovteti, 82 (2) (Sprirgog).

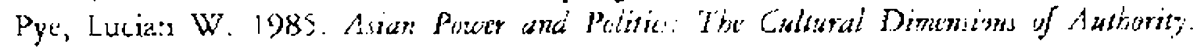
Carrbricge, MA: Hanaret Unversty Press.

Shedle:, Andrens. 1999. "Conceprializing Accountability." In The Self-Restraining Siate: Porier and "Accountabilit; in Neic Demoracia, ecis. Ancreas Scredler, Larn Diamond and Marc Plartner. Boulder, CO: Lynne Kuenocr Pujlisters.

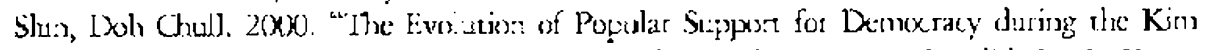

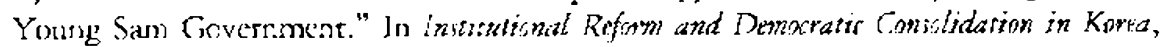
eds. Iarry Diamon:l and Doh Chi'l Snin. Stanford, CA: Hoover Institution Press.

Stenberg, Darid : 1995. "Tre Repuislic of Karea: Plualiziag Politics." Ir. Demaracy in

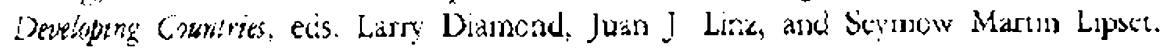
3ou'der, CO: Lyne Ricurer Pulvishers.

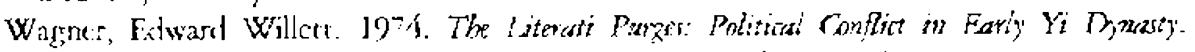
Cambridge, MA: East Asian Research Certer, Harvaré Liaivexity. 